\title{
Streptococcal taxonomy based on genome sequence analyses
}

\section{[version 1; peer review: 2 approved]}

\section{Cristiane C Thompson*, Vanessa E Emmel ${ }^{*}$, Erica L Fonseca, Michel A Marin, Ana Carolina P Vicente}

Laboratory of Molecular Genetics of Microorganisms, Oswaldo Cruz Institute (IOC - FIOCRUZ) Avenida Brasil 4365, Manguinhos, Rio de Janeiro, P. O. Box 926, Zip Code 21040-360, Brazil

${ }^{*}$ Equal contributors

V1 First published: 01 Mar 2013, 2:67

https://doi.org/10.12688/f1000research.2-67.v1

Latest published: 01 Mar 2013, 2:67

https://doi.org/10.12688/f1000research.2-67.v1

\section{Abstract}

The identification of the clinically relevant viridans streptococci group, at species level, is still problematic. The aim of this study was to extract taxonomic information from the complete genome sequences of 67 streptococci, comprising 19 species, by means of genomic analyses, multilocus sequence analysis (MLSA), average amino acid identity (AAI), genomic signatures, genome-to-genome distances (GGD) and codon usage bias. We then attempted to determine the usefulness of these genomic tools for species identification in streptococci. Our results showed that MLSA, AAI and GGD analyses are robust markers to identify streptococci at the species level, for instance, S. pneumoniae, S. mitis, and S. oralis. A Streptococcus species can be defined as a group of strains that share $\geq 95 \%$ DNA similarity in MLSA and AAI, and $>70 \%$ DNA identity in GGD. This approach allows an advanced understanding of bacterial diversity.

\section{Keywords}

Comparative Genomic, Genomic Taxonomy, Streptococci species

\section{Open Peer Review}

Approval Status

1

2

version 1

01 Mar 2013

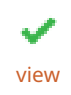

\section{$\checkmark$}

1. Tomoo Sawabe, Graduate School of Fisheries Sciences, Hokkaido University, Hakodate,

Japan

2. Bruno Gomez-Gil, Mazatlán Unit for

Aquaculture and Environmental

Management, Mazatlán, Mexico

Any reports and responses or comments on the article can be found at the end of the article.

This article is included in the Phylogenetics

collection. 
Corresponding author: Cristiane C Thompson (thompson@ioc.fiocruz.br)

Competing interests: No relevant competing interests were disclosed.

Grant information: The author(s) declared that no grants were involved in supporting this work.

Copyright: $\odot 2013$ Thompson CC et al. This is an open access article distributed under the terms of the Creative Commons Attribution License, which permits unrestricted use, distribution, and reproduction in any medium, provided the original work is properly cited. Data associated with the article are available under the terms of the Creative Commons Zero "No rights reserved" data waiver (CC0 1.0 Public domain dedication).

How to cite this article: Thompson CC, Emmel VE, Fonseca EL et al. Streptococcal taxonomy based on genome sequence analyses [version 1; peer review: 2 approved] F1000Research 2013, 2:67 https://doi.org/10.12688/f1000research.2-67.v1

First published: 01 Mar 2013, 2:67 https://doi.org/10.12688/f1000research.2-67.v1 


\section{Introduction}

Bacteria are subjected to numerous forces driving their diversification. As a consequence, different strains of a single bacterial species sometimes have the ability to explore distinct niches, to be pathogenic or non-pathogenic and to present different metabolic pathways ${ }^{1,2}$. In such a scenario, the identification of bacteria isolates to the species level is a hard task ${ }^{1,2}$.

Currently, the genus Streptococcus comprises 99 recognized species, many of which are associated with disease in humans and animals (http://www.bacterio.cict.fr/s/streptococcus.html). The viridans group streptococci (VGS) encompass four phylogenetic clusters: Mitis, Mutans, Salivarius and Anginosus, which are part of the human microbiota, being isolated mainly from the oral cavity, gastrointestinal and genitourinary tracts ${ }^{3}$. The Mitis group currently includes the important pathogen $S$. pneumoniae and 12 other recognized species, S. australis, S. cristatus (formerly S. crista), S. gordonii, S. infantis, S.mitis, S. oligofermentans, S. oralis, S. parasanguinis (formerly S. parasanguis), S. peroris, S. pseudopneumoniae, S. sanguinis (formerly $S$. sanguis) and $S$. sinensis. The Anginosus group includes three recognized species, S. anginosus, $S$. constellatus (including two subspecies $S$. constellatus subsp. constellatus and S. constellatus pharyngis) and S. intermedius, and the Salivarius group includes $S$. salivarius, $S$. vestibularis, and S. thermophilus.

Currently, bacterial species are considered to be a group of strains (including the type strain) that are characterized by a certain degree of phenotypic consistency, showing $>70 \%$ DNA-DNA hybridization values and over $97 \% 16 \mathrm{~S}$ rRNA sequence similarity ${ }^{4,5}$. Identification of streptococci is based on the current taxonomic standards using a combination of 16S rRNA gene sequence analyses, DNADNA hybridization, serologic and phenotypic data; however, they have been strikingly resistant to satisfactory classification, reflected in frequently changing nomenclature ${ }^{6,7}$. For instance, the $16 \mathrm{~S}$ rRNA gene sequences of $S$. mitis and $S$. oralis are almost identical (> $99 \%$ ) to $S$. pneumoniae, making the use of this information alone insufficient to distinguish these species $^{8}$.

Recent studies have used whole genome analysis to determine the taxonomic relationships among bacterial species ${ }^{9-14}$. In order to determine the robustness of genomic markers in streptococci species delineation, we analyzed a collection of 67 complete genomes. The availability of whole genome sequences of several closely related species, for instance, S. mitis - S. oralis - S. pneumoniae, and S. salivarius - S. thermophilus - S. vestibularis, formed an ideal test case for the establishment of the genomic taxonomy of streptococci.

\section{Material and methods}

Genome sequence data

The genomic sequences of 67 streptococci that were publicly available for download by June $2^{\text {nd }}, 2011$ at the National Center for Biotechnology Information (NCBI) under the project accession number indicated in Table 1 were used in this study. The following analyses were performed according to Thompson et al. (2009) ${ }^{13}$ and are briefly described below.
16S rRNA gene sequence analysis and multilocus sequence analysis (MLSA)

The 16S rRNA gene sequences and the gene sequences used for MLSA were obtained from GenBank (http://www.ncbi.nlm.nih.gov). The MLSA approach was based on the concatenated sequences of five house-keeping genes ( $\operatorname{rro} E, d d l, g k i$, pheS and $\operatorname{rec} A)^{15,16}$. The concatenated sequences were aligned with ClustalX program ${ }^{17}$. The phylogenetic inference was based on the neighbour-joining genetic distance method $(\mathrm{NJ})^{18}$ using MEGA5 ${ }^{19}$. Distance estimations were obtained according to the Kimura-2-parameter ${ }^{20}$ for 16S rRNA gene and MLSA. The reliability of each tree topology was checked by 2000 bootstrap replications ${ }^{21}$.

Average amino acid identity (AAI)

The AAI of all conserved protein-coding genes was calculated as described previously ${ }^{22}$. Conserved protein-coding genes between a pair of genomes were determined by whole-genome pairwise sequence comparisons using the BLASTp algorithm ${ }^{23}$. For these comparisons, all protein-coding sequences (CDSs) from one genome were searched against the genomic sequence of the other genome. The genetic relatedness between a pair of genomes was measured by the AAI of all conserved genes between the two genomes as computed by the BLAST algorithm. By this approach, a value of $<95 \%$ AAI of protein-coding genes indicates separate species.

\section{Codon usage}

Codon usage bias was calculated for each genome. The effective number of codons used in a sequence $(N c)^{24}$ was calculated using CHIPS (http://emboss.bioinformatics.nl/cgi-bin/emboss/chips) with the default parameters.

Determination of dinucleotide relative abundance values and genomic dissimilarity

Mononucleotide and dinucleotide frequencies were calculated using COMPSEQ (http://emboss.bioinformatics.nl/cgi-bin/emboss/ compseq) with default parameters. Dinucleotide relative abundances $(\rho * X Y)$ were calculated using the equation $\rho * X Y=f X Y / f X f Y$ where $\mathrm{fXY}$ denotes the frequency of dinucleotide $\mathrm{XY}$, and $\mathrm{fX}$ and $\mathrm{fY}$ denote the frequencies of $X$ and $Y$, respectively. The difference in genome signature between two sequences is expressed by the genomic dissimilarity $\left(\delta^{*}\right)$, which is the average absolute dinucleotide of relative abundance difference between two sequences, and were calculated using the equation: $\delta *(f, g)=1 / 16 \Sigma \mid \rho * X Y$ (f) $-\rho * X Y$ (g) $\mid$ (multiplied by 1000 for convenience), where the sum extends over all dinucleotides ${ }^{25}$.

\section{Genome-to-genome distances (GGD)}

The genome distance was calculated using genome-to-genome distance calculator (GGDC) ${ }^{26}$. Distances between a pair of genomes were determined by whole-genome pairwise sequence comparisons using $\mathrm{BLAST}^{23}$. For these comparisons, algorithms were used to determine high-scoring segment pairs (HSPs) for inferring intergenomic distances for species delimitation. The corresponding distance threshold can be used for species delimitation ${ }^{26}$. 
Table 1. Genomic features of the streptococci. G+C content (\%): guanine + cytosine content (\%). No. of CDs: number of coding DNA sequence. Nc: effective number of codons.

\begin{tabular}{|c|c|c|c|c|c|}
\hline Organism & GenBank accession no. & $\begin{array}{l}\text { Genome size } \\
\text { (nt) }\end{array}$ & $\begin{array}{l}\text { G+C content } \\
(\%)\end{array}$ & $\begin{array}{l}\text { No. of } \\
\text { CDS }\end{array}$ & Nc \\
\hline S. agalactiae $\mathrm{A} 909$ & CP000114 & $2,127,839$ & 35 & 1996 & 44.9 \\
\hline S. agalactiae NEM316 & AL732656 & $2,211,485$ & 35 & 2094 & 45.2 \\
\hline S. agalactiae 2603 VR & AE009948 & $2,160,267$ & 35 & 2124 & 45.1 \\
\hline S. anginosus F0211 & АЕСТО0000000 & $1,993,709$ & 38 & 2035 & 50.6 \\
\hline S. bovis ATCC 700338 & AEEL00000000 & $2,050,893$ & 37 & 2088 & 44.5 \\
\hline S. downei F0415 & AEKN00000000 & $2,239,421$ & 43 & 2204 & 54.4 \\
\hline S. dysgalactiae subsp. equisimilis GGS-124 & AP010935 & $2,106,340$ & 39 & 2094 & 50.3 \\
\hline S. equi subsp. equi 4047 & FM204883 & $2,253,793$ & 41 & 2001 & 52.6 \\
\hline S. equi subsp. zooepidemicus & FM204884 & $2,149,868$ & 41 & 1869 & 52.4 \\
\hline S. equi subsp. zooepidemicus MGCS10565 & СР001129 & $2,024,171$ & 41 & 1893 & 52.3 \\
\hline S. gallolyticus subsp. gallolyticus TX20005 & AEEM00000000 & $2,214,091$ & 37 & 2218 & 44.5 \\
\hline S. gallolyticus UCN34 & FN597254 & $2,350,911$ & 37 & 2223 & 44.4 \\
\hline S. gordonii str. Challis substr. $\mathrm{CH} 1$ & CP000725 & $2,196,662$ & 40 & 2051 & 52.4 \\
\hline S. infantis SK1302 & AEDY00000000 & $1,792,252$ & 39 & 2102 & 48.9 \\
\hline S. infantarius subsp. infantarius ATCC BAA-102 & ABJK00000000 & $1,925,087$ & 37 & 2051 & 44.0 \\
\hline S. mitis B6 & FN568063 & $2,146,611$ & 39 & 2004 & 50.4 \\
\hline S. mitis SK321 & AEDT00000000 & $1,873,702$ & 40 & 1757 & 49.8 \\
\hline S. mutans NN2025 & AP010655 & $2,013,587$ & 36 & 1895 & 46.4 \\
\hline S. mutans UA159 & AE014133 & $2,030,921$ & 36 & 1960 & 46.5 \\
\hline S. oralis ATCC 35037 & AEDW00000000 & $1,884,712$ & 41 & 1793 & 51.4 \\
\hline S. parasanguinis ATCC 15912 & ADVN00000000 & $2,124,730$ & 41 & 2035 & 52.8 \\
\hline S. parasanguinis F0405 & AEKM00000000 & $2,050,302$ & 41 & 1978 & 52.9 \\
\hline S. pneumoniae AP200 & СР002121 & $2,130,580$ & 39 & 2216 & 50.3 \\
\hline S. pneumoniae ATCC 700669 & FM211187 & $2,221,315$ & 39 & 1990 & 50.0 \\
\hline S. pneumoniae CGSP14 & СР001033 & $2,209,198$ & 39 & 2206 & 50.3 \\
\hline S. pneumoniae D39 & CP000410 & $2,046,115$ & 39 & 1914 & 49.8 \\
\hline S. pneumoniae G54 & CP001015 & $2,078,953$ & 39 & 2114 & 50.0 \\
\hline S. pneumoniae Hungary19A-6 & СР000936 & $2,245,615$ & 39 & 2155 & 50.2 \\
\hline S. pneumoniae INV104 & FQ312030 & $2,142,122$ & 39 & 1824 & 49.9 \\
\hline S. pneumoniae INV200 & FQ312029 & $2,093,317$ & 39 & 1930 & 50.0 \\
\hline S. pneumoniae JJA & СР000919 & $2,120,234$ & 39 & 2123 & 50.2 \\
\hline S. pneumoniae OXC141 & FQ312027 & $2,036,867$ & 39 & 1824 & 49.9 \\
\hline S. pneumoniae P1031 & СР000920 & $2,111,882$ & 39 & 2073 & 50.1 \\
\hline S. pneumoniae R6 & AE007317 & $2,038,615$ & 39 & 2042 & 50.1 \\
\hline S. pneumoniae Taiwan19F-14 & СР000921 & $2,112,148$ & 39 & 2044 & 50.1 \\
\hline S. pneumoniae TCH843119A & СР001993 & $2,088,772$ & 39 & 2275 & 50.4 \\
\hline S. pneumoniae TIGR4 & AE005672 & $2,160,842$ & 39 & 2105 & 50.0 \\
\hline S. pneumoniae $670-6 \mathrm{~B}$ & СР002176 & $2,240,045$ & 39 & 2352 & 50.4 \\
\hline S. pneumoniae 70585 & CP000918 & $2,184,682$ & 39 & 2202 & 50.1 \\
\hline S. pseudoporcinus SPIN 20026 & AENS00000000 & $2,111,372$ & 36 & 2030 & 48.6 \\
\hline S. pyogenes MGAS315 & AE014074 & $1,900,521$ & 38 & 1865 & 49.1 \\
\hline S. pyogenes MGAS2096 & СР000261 & $1,860,355$ & 38 & 1898 & 49.4 \\
\hline S. pyogenes MGAS5005 & СР000017 & $1,838,554$ & 38 & 1865 & 48.9 \\
\hline S. pyogenes MGAS6180 & CP000056 & $1,897,573$ & 38 & 1894 & 48.9 \\
\hline S. pyogenes MGAS8232 & AE009949 & $1,895,017$ & 38 & 1839 & 49.0 \\
\hline S. pyogenes MGAS9429 & СР000259 & $1,836,467$ & 38 & 1877 & 49.0 \\
\hline S. pyogenes MGAS10270 & СР000260 & $1,928,252$ & 38 & 1986 & 49.0 \\
\hline S. pyogenes MGAS10394 & СР000003 & $1,899,877$ & 38 & 1886 & 49.2 \\
\hline S. pyogenes MGAS10750 & СР000262 & $1,937,111$ & 38 & 1979 & 49.1 \\
\hline S. pyogenes M1 GAS & AE004092 & $1,852,441$ & 38 & 1696 & 48.8 \\
\hline S. pyogenes NZ131 & СР000829 & $1,815,785$ & 38 & 1700 & 48.8 \\
\hline
\end{tabular}




\begin{tabular}{|c|c|c|c|c|c|}
\hline Organism & GenBank Accession no. & $\begin{array}{l}\text { Genome size } \\
\text { (nt) }\end{array}$ & $\begin{array}{l}\text { G+C content } \\
(\%)\end{array}$ & $\begin{array}{l}\text { No. of } \\
\text { CDS }\end{array}$ & Nc \\
\hline S. pyogenes SSI-1 & BA000034 & $1,894,275$ & 38 & 1859 & 49.1 \\
\hline S. pyogenes str. Manfredo & AM295007 & $1,841,271$ & 38 & 1745 & 48.9 \\
\hline S. salivarius SK126 & ACLO00000000 & $2,128,332$ & 40 & 1992 & 47.0 \\
\hline S. sanguinis ATCC 49296 & AEPO00000000 & $2,054,852$ & 41 & 2013 & 51.7 \\
\hline S. sanguinis SK36 & СР000387 & $2,388,435$ & 43 & 2270 & 54.5 \\
\hline S. sanguinis VMC66 & AEVH00000000 & $2,311,949$ & 43 & 2260 & 54.5 \\
\hline S. suis BM407 & FM252032 & $2,146,229$ & 41 & 1932 & 52.0 \\
\hline S. suis GZ1 & СР000837 & $2,038,034$ & 41 & 1979 & 52.4 \\
\hline S. suis $\mathrm{P} 17$ & AM946016 & $2,007,491$ & 41 & 1824 & 51.9 \\
\hline S. suis SC84 & FM252031 & $2,095,898$ & 41 & 1898 & 52.0 \\
\hline S. thermophilus CNRZ1066 & СР000024 & $1,796,226$ & 39 & 1915 & 47.0 \\
\hline S. thermophilus LMD-9 & CP000419 & $1,856,368$ & 39 & 1709 & 46.8 \\
\hline S. thermophilus LMG 18311 & СР000023 & $1,796,846$ & 39 & 1888 & 46.9 \\
\hline S. thermophilus ND03 & СР002340 & $1,831,949$ & 39 & 1919 & 46.8 \\
\hline S. uberis $0140 \mathrm{~J}$ & AM946015 & $1,852,352$ & 36 & 1762 & 46.4 \\
\hline S. vestibularis F0396 & AEKO00000000 & $2,022,289$ & 39 & 1979 & 47.1 \\
\hline
\end{tabular}

\section{Results and discussion}

In this work we compared complete genomes for 67 streptococci comprising 19 species to address their taxonomic position. A previous study with a small set of streptococci genomes (eight) and species (four), using a combination of several genomic analyses, showed the applicability of this approach in streptococci taxonomy ${ }^{9}$. Overall our analysis, using a large data set, showed that genomic taxonomy is an accurate approach to clearly define the streptococci species. The taxonomic resolution of the 16S rRNA, AAI, MLSA, GGD and codon usage analysis for streptococci species definition is summarized in Table 2.

\section{General genomic features}

The complete genome of the streptococci comprised a single chromosome. The estimated size of the genomes ranged from $1.7 \mathrm{Mb}$ (S. infantis) to $2.3 \mathrm{Mb}$ (S. sanguinis). The number of CDS varied from 1,700 (S. pyogenes) to 2,352 (S. pneumoniae) (Table 1). The average $\mathrm{G}+\mathrm{C}$ content of streptococci genomes ranged from $35 \%$ to $43 \%$. These species presented a variable interspecies genome size and $\mathrm{G}+\mathrm{C}$ content, indicating heterogeneity within the genus Streptococcus. One of the reasons for this variability could be associated with the frequent occurrence of horizontal gene transfer events ${ }^{27-29}$.

\section{Phylogenetic reconstructions by 16S rRNA and MLSA}

MLSA and 16S rRNA phylogenetic trees showed similar topologies (Figure 1). The MLSA was performed using five instead of the seven genes applied in the pneumococcus multilocus sequence typing (MLST) scheme (http://spneumoniae.mlst.net/) ${ }^{15,16}$. Three genes, aroE, $d d l$ and $g k i$, are from the MLST scheme, and pheS and recA were included in this work. The concatenation of these genes (7741 bp) allowed an accurate delineation of the streptococci species considered here. The nucleotide sequence similarities were much lower for MLSA than 16S rRNA gene. A pairwise comparison of MLSA among the species revealed sequence similarity between $67 \%$ and $100 \%$, while the 16S rRNA gene sequence similarities varied from $92 \%$ to $100 \%$. At the intraspecies level, the similarity values ranged from $95 \%$ to $100 \%$ for MLSA, and $99 \%$ to $100 \%$ for the 16S rRNA gene sequences. The closest species within the Mitis (S. pneumoniae - S. oralis - S. mitis) and Salivarius groups (S. vestibulares - S. salivarius - S. thermophilus) were clearly placed apart from each other by MLSA, while these species had almost identical 16S rRNA gene sequences ( $\geq 99 \%$ sequence similarity). A previously study showed that $r e c A$ analysis is a valuable tool for proper identification of pneumococci in routine diagnostics, but limitations on discrimination of other members of the Mitis group were observed $^{30}$. S. sanguinis ATCC 49296 showed a much closer relationship with $S$. oralis ATCC 35037 T (95\% similarity) than to other $S$. sanguinis strains (77\% similarity), suggesting it belongs to the species $S$. oralis. In addition, S. bovis ATCC 700338 was placed in the $S$. gallolyticus cluster with $98 \%$ MLSA sequence similarity. This work showed that MLSA, using this new combination of five concatenated genes (aroE, $d d l$, gki, pheS and recA), distinct from the Streptococcus MLST scheme, allowed a proper identification of most streptococci species, even within the VGS group.

\section{Average amino acid identity (AAI)}

The percentage of average amino acid identity (AAI) among streptococci species ranges from $68 \%$ to $94 \%$, while within species it varies from $95 \%$ to $100 \%$. The VGS species S. pneumoniae, S. mitis and S. oralis shared 89-93\% AAI. The species S. salivarius, S. thermophilus and S. vestibularis showed a maximum AAI of $93 \%$. S. sanguinis ATCC 49296 and S. oralis ATCC 35037 showed 96\% identity and S. bovis ATCC 700338 and S. gallolyticus strains had $98 \%$ identity. These findings suggest that strains ATCC 49296 and ATCC 700338 belong to the species $S$. oralis and S. gallolyticus, respectively. According to our analyses the AAI and MLSA are the most useful genomic features for the elucidation of streptococci taxonomy.

\section{Genome signature}

The genomic dissimilarity values among streptococci were between 3 and 127, while the intraspecies values were between 0 and 17 . Streptococci within the VGS group, for instance, S. salivarius, 
Table 2. Taxonomic resolution of genomic analyses of streptococci species. MLSA: multilocus sequence analysis. AAI: amino acid identity. GGD: genome to genome distance. Nc: effective number of codons.

\begin{tabular}{lccccc} 
& 16S rRNA (\%) & MLSA (\%) & AAI (\%) & GGD (\%) & Codon usage (Nc) \\
\hline Intraspecies & $\geq 99$ & $\geq 95$ & $\geq 95$ & $>70$ & - \\
\hline S. pyogenes & $\geq 99$ & $\geq 98$ & $>97$ & $>70$ & 49 \\
\hline S. agalactiae & 99 & 100 & 98 & $>70$ & 45 \\
\hline S. equi & 99 & 98 & $>96$ & $>70$ & 52 \\
\hline S. suis & 100 & 100 & 100 & $>70$ & 52 \\
\hline S. pneumoniae & 99 & $\geq 97$ & $>97$ & $>70$ & 50 \\
S.thermophilus & 99 & 100 & $>97$ & $>70$ & 47 \\
\hline Interspecies & $\leq 99$ & $<95$ & $<95$ & $<70$ & $44-54$ \\
\hline S. thermophilus-salivarius-vestibularis & 99 & $<94$ & $<92$ & $<70$ & 47 \\
\hline S. pneumoniae-mitis-oralis & $>99$ & $<94$ & $<93$ & $<70$ & $50-51$
\end{tabular}

\section{Raw data: MLSA nucleotide sequences \\ 2 Data Files \\ http://dx.doi.org/10.6084/m9.figshare.157260}

Raw data: average amino acid identity

2 Data Files

http://dx.doi.org/10.6084/m9.figshare.157261

Raw data: genomic signatures

2 Data Files

http://dx.doi.org/10.6084/m9.figshare.157262

S. thermophilus and $S$. vestibularis species, showed dissimilarity values between 5 and 12 and S. pneumoniae, S. mitis and S. oralis species had dissimilarity values between 3 and 14 . Thus, there was not a clear differentiation of these closely related species within the VGS group on the basis of the genomic dissimilarity values. This could be due to the extensive recombination and horizontal gene transfer events which occur between closely related streptococci species that share ecological niches ${ }^{12,30}$.

On the other hand, species within the Pyogenic group had a distinct genomic signature, with values ranging from 13 to 85 . However, genome signatures alone have significant limitations when used as phylogenetic markers for differentiating members of the VGS. The exact mechanisms that generate and maintain the genome signatures are complex, but possibly involve differences in speciesspecific compositional bias, i.e., $\mathrm{G}+\mathrm{C}$ content, $\mathrm{G}+\mathrm{C}$ and $\mathrm{A}+\mathrm{T}$ skews, codon bias, and mutation bias ${ }^{32,33}$.

\section{Codon usage bias (Nc)}

$N c$ values provide a meaningful measure of the extent of codon preference in a genome, values range between 20 (extremely biased genome where one codon is used per amino acid) and 61 (all synonymous codons are used). Within the set of 67 complete streptococci genomes examined in this study, the $N c$ ranged from 44.0 to 54.5 (Table 1). For instance, $S$. pneumoniae - S. oralis - $S$. mitis species had $N c$ values of 50, 51 and 50, respectively. The Salivarius group (S. vestibulares - S. salivarius - S. thermophilus), and S. bovis ATCC 700338 - S. gallolyticus showed $N c$ values of 47 and 44.5, respectively. Overall, codon usage bias was very similar among the streptococci species investigated. However, S. sanguinis ATCC 49296 showed a much closer $N c$ value with the $S$. oralis ATCC 35037 (51.7 and 51.4, respectively) than other $S$. sanguinis strains (54.5), which was in agreement with the other analyses used in this study.

\section{Genome distance analysis}

The GGD was calculated only for closely related species that were not differentiated by $16 \mathrm{~S}$ rRNA gene sequence analysis (Figure 1). Based on GGD analysis the species within the Mitis and Salivarius groups were identified as separate species, showing GGD values analogous to the $<70 \%$ discriminatory value used for DNA-DNA hybridization. Conversely, S. bovis ATCC 700338 and S. gallolyticus were identified as belonging to the same species by GGD.

S. bovis ATCC 700338 (biotype II) and S. gallolyticus as well as S. sanguinis ATCC 49296 and S. oralis ATCC 35037T were not separated and, therefore, according to this analysis would be classified as the same species, respectively. It was shown that $S$. bovis biotype I and II/2 isolates were, in fact, S. gallolyticus $^{34}$, and S. sanguinis ATCC 49296 was placed into S. oralis species by GGD analysis. A misidentification of S. sanguinis ATCC 49296 has already been shown by means of biochemical and serological properties by Narikawa and colleagues ${ }^{35}$.

Another interesting result is that the $S$. parasanguinis ATCC 15912 and F0405 strains were found to be at the upper limits for definition as members of the same species based on different genomic analyses. For instance, they shared 95\% AAI, 94\% identity by MLSA, a value of 17 on the basis of genomic signature and $<70 \%$ similarity in GGD. Therefore, based on these genomic 


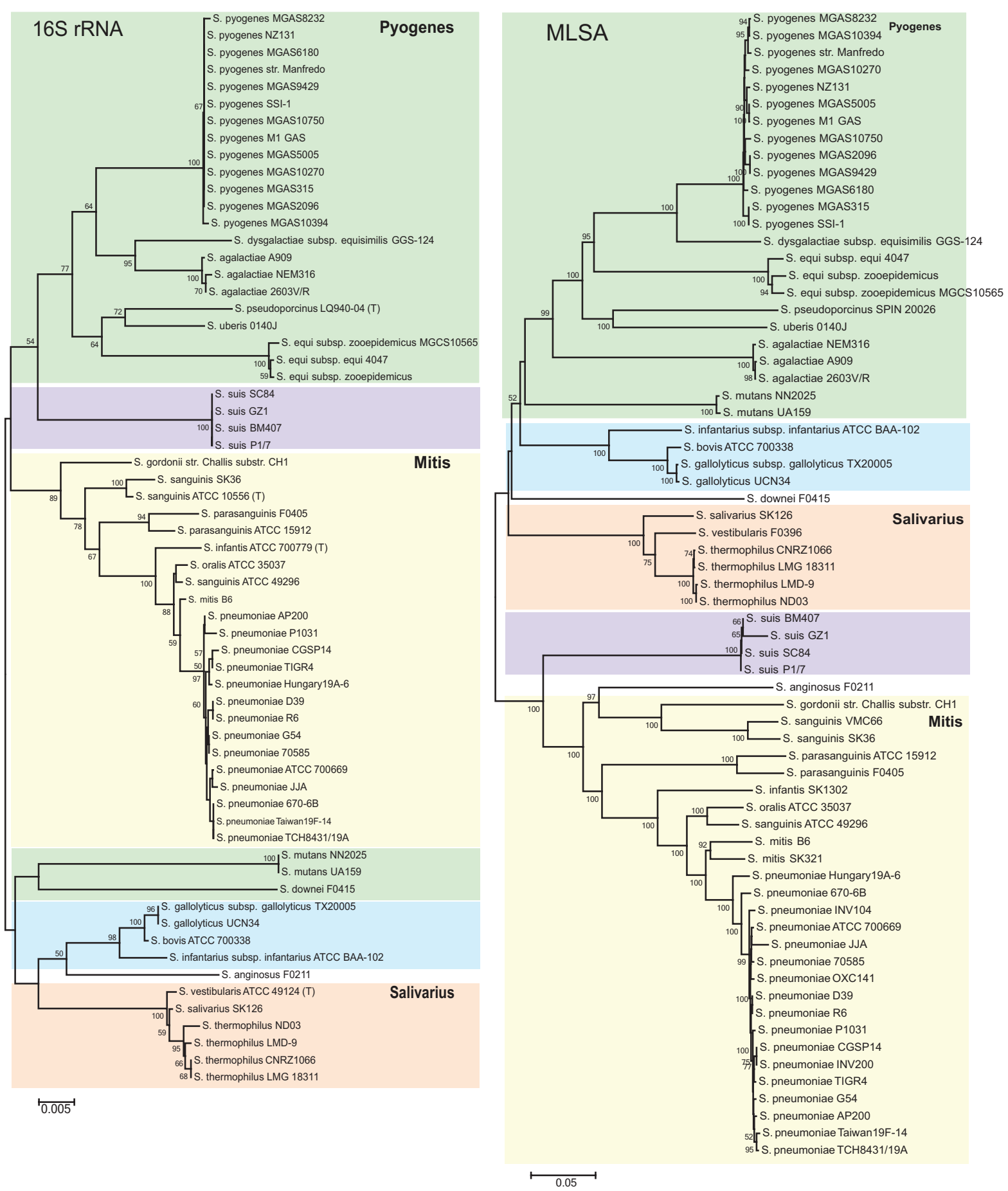

Figure 1. Neighbor-joining tree based on 16S rRNA gene sequences and MLSA concatenated sequences of Streptococcus. The numbers at the nodes indicate the values of bootstrap statistics after 2000 replications, and values below 50\% are not shown. Bars, 0.005\% and $0.02 \%$ estimated sequence divergence. 
markers, these $S$. parasanguinis strains could, in fact, be separate species. This data reflects the complexity of bacterial species delineation, since these organisms are all under a constant evolutionary process.

\section{Conclusion}

The delineation of closely related streptococci species was evident in this genomic study. Different methods produced different levels of taxonomic resolution. The methods with the higher resolution for species identification were MLSA and AAI, while closely related species had similar $N c$ values and genomic signatures. Based on the genomic analyses, a Streptococcus species can be defined as a group of strains that shares $\geq 95 \%$ identity in MLSA and AAI, and $>70 \%$ identity in GGD. This definition may be useful to advance the taxonomy of Streptococcus. This approach allows an advanced understanding of bacterial diversity and identification.
Author contributions

CCT and VEE carried out the computational and genomic analyses and analyzed the results. All authors (ACPV, CCT, ELF, MAM and VEE) participated in discussing and writing the manuscript. All authors have agreed to the final contents of the article.

\section{Competing interests}

No relevent competing interests were disclosed.

\section{Grant information}

VEE had a PRODOC-CAPES fellowship. CCT has a PNPDCAPES fellowship, ELF has a PNPD-FAPERJ fellowship and MAM has a CAPES fellowship.
1. Gevers D, Cohan FM, Lawrence JG, et al:: Opinion: Re-evaluating prokaryotic species. Nat Rev Microbiol. 2005; 3(9): 733-9. PubMed Abstract | Publisher Full Text

2. Cohan FM, Koeppel AF: The origins of ecological diversity in prokaryotes. Curr Biol. 2008; 18(21): R1024-34. PubMed Abstract | Publisher Full Text

3. Alam S, Brailsford SR, Whiley RA, et al.: PCR-Based methods for genotyping viridans group streptococci. J Clin Microbiol. 1999; 37(9): 2772-6. PubMed Abstract | Free Full Text

4. Stackebrandt E, Goebel BM: Taxonomic Note: A place for DNA-DNA reassociation and $16 \mathrm{~S}$ ribosomal-RNA sequence analysis in the present species definition in bacteriology. Int J Syst Bacteriol. 1994; 44(4): 846-849. Publisher Full Text

5. Wayne LG, Brenner DJ, Colwell RR, et al.: Report of the ad hoc committee on reconciliation of approaches to bacterial systematics. Int $J$ Syst Bacteriol. 1987; 37(4): 463-464 Publisher Full Text

6. Hoshino T, Fujiwara T, Kilian M: Use of phylogenetic and phenotypic analyses to identify nonhemolytic streptococci isolated from bacteremic patients. J Clin Microbiol. 2005; 43(12): 6073-85. PubMed Abstract | Publisher Full Text | Free Full Text

7. Kawamura $Y$, Hou XG, Sultana $F$, et al: Determination of $16 \mathrm{~S}$ rRNA sequences of Streptococcus mitis and Streptococcus gordonii and phylogenetic relationships among members of the genus Streptococcus. Int J Syst Bacteriol. 1995; 45(2): 406-8

PubMed Abstract | Publisher Full Text | Free Full Text

8. Suzuki N, Seki M, Nakano Y, et al:: Discrimination of Streptococcus pneumoniae from viridans group streptococci by genomic subtractive hybridization. J Clin Microbiol. 2005; 43(9): 4528-34. PubMed Abstract | Publisher Full Text | Free Full Text

9. Coenye T, Vandamme P: Extracting phylogenetic information from whole-genome sequencing projects: the lactic acid bacteria as a test case. Microbiology. 2003; 149(pt 12): 3507-17. PubMed Abstract | Publisher Full Text

10. Coenye T, Gevers D, Van de Peer Y, et al.: Towards a prokaryotic genomic taxonomy. FEMS Microbiol Rev. 2005; 29(2): 147-67. PubMed Abstract | Publisher Full Text

11. Richter SS, Heilmann KP, Dohrn CL, et al.: Accuracy of phenotypic methods for identification of Streptococcus pneumoniae isolates included in surveillance programs. J Clin Microbiol. 2008; 46(7): 2184-8. PubMed Abstract | Publisher Full Text | Free Full Text
12. Croucher NJ, Harris SR, Fraser C, et al.: Rapid pneumococcal evolution in response to clinical interventions. Science. 2011; 331(6016): 430-4. PubMed Abstract | Publisher Full Text | Free Full Text

13. Thompson CC, Vicente ACP, Souza RC, et al.: Genomic taxonomy of Vibrios. BMC Evol Biol. 2009; 9: 258.

PubMed Abstract | Publisher Full Text | Free Full Text

14. Thompson CC, Vieira NM, Vicente AC, et al:: Towards a genome based taxonomy of Mycoplasmas. Infect Genet Evol. 2011; 11(7): 1798-804. PubMed Abstract | Publisher Full Text

15. Enright MC, Spratt BG: A multilocus sequence typing scheme for Streptococcus pneumoniae: identification of clones associated with serious invasive disease. Microbiology. 1998; 144(Pt 11): 3049-60. PubMed Abstract | Publisher Full Text

16. Hanage WP, Fraser $C$, Spratt BG: Sequences, sequence clusters and bacterial species. Philos Trans R Soc Lond B Biol Sci. 2006; 361(1475): 1917-27. PubMed Abstract | Publisher Full Text | Free Full Text

17. Thompson JD, Gibson TJ, Plewniak F, et al.: The CLUSTAL $\mathbf{X}$ windows interface: flexible strategies for multiple sequence alignment aided by quality analysis tools. Nucleic Acids Res. 1997; 25(24): 4876-82. PubMed Abstract | Publisher Full Text | Free Full Text

18. Saitou N, Nei M: The neighbor-joining method: a new method for reconstructing phylogenetic trees. Mol Biol Evol. 1987; 4(4): 406-25. PubMed Abstract

19. Tamura K, Peterson D, Peterson N, et al:: MEGA5: molecular evolutionary genetics analysis using maximum likelihood, evolutionary distance, and maximum parsimony methods. Mol Biol Evol. 2011; 28(10): 2731-9. PubMed Abstract | Publisher Full Text | Free Full Text

20. Kimura M: A simple method for estimating evolutionary rates of base substitutions through comparative studies of nucleotide sequences. J Mol Evol. 1980; 16(2): 111-120. PubMed Abstract | Publisher Full Text

21. Felsenstein J: Confidence Limits on Phylogenies: An Approach Using the Bootstrap. Evolution. 1985; 39(4): 783-791. Publisher Full Text

22. Konstantinidis KT, Tiedje JM: Towards a genome-based taxonomy for prokaryotes. J Bacteriol. 2005; 187(18): 6258-64. PubMed Abstract | Publisher Full Text | Free Full Text

23. Altschul SF, Madden TL, Schäffer AA, et al: Gapped BLAST and PSI-BLAST: a new generation of protein database search programs. Nucleic Acids Res. 1997; 25(17): 3389-402. PubMed Abstract | Publisher Full Text | Free Full Text 
24. Wright $\mathrm{F}$ : The 'effective number of codons' used in a gene. Gene. 1990; 87(1): 23-9. PubMed Abstract | Publisher Full Tex

25. Karlin S, Mrázek J, Campbell AM: Compositional biases of bacterial genomes and evolutionary implications. J Bacteriol. 1997; 179(12): 3899-913. PubMed Abstract | Free Full Text

26. Auch AF, Klenk HP, Göker M: Standard operating procedure for calculating genome-to-genome distances based on high-scoring segment pairs. Stand Genomic Sci. 2010; 2(1): 142-8. PubMed Abstract | Publisher Full Text | Free Full Text

27. Zhang $\mathrm{A}$, Yang M, Hu P, et al:: Comparative genomic analysis of Streptococcus suis reveals significant genomic diversity among different serotypes. BMC genomics. 2011; 12: 523 .

PubMled Abstract | Publisher Full Text | Free Full Text

28. Bellanger $\mathrm{X}$, Roberts $\mathrm{AP}$, Morel $\mathrm{C}$, et al:: Conjugative transfer of the integrative conjugative elements ICESt 1 and ICESt3 from Streptococcus thermophilus. J Bacteriol. 2009; 191(8): 2764-75.

PubMed Abstract | Publisher Full Text | Free Full Text

29. Harvey RM, Stroeher UH, Ogunniyi AD, et al:: A variable region within the genome of Streptococcus pneumoniae contributes to strain-strain variation in virulence. PloS One. 2011; 6(5): e19650.

PubMed Abstract | Publisher Full Text | Free Full Text
30. Zbinden A, Köhler N, Bloemberg GV: recA-based PCR assay for accurate differentiation of Streptococcus pneumoniae from other viridans streptococci. J Clin Microbiol. 2011; 49(2): 523-7.

PubMed Abstract | Publisher Full Text | Free Full Text

31. Donati $\mathrm{C}$, Hiller NL, Tettelin $\mathrm{H}$, et al:: Structure and dynamics of the pan-genome of Streptococcus pneumoniae and closely related species. Genome Biol. 2010; 11(10): R107.

PubMed Abstract | Publisher Full Text | Free Full Text

32. Karlin S: Global dinucleotide signatures and analysis of genomic heterogeneity. Curr Opin Microbiol. 1998; 1(15): 598-610. PubMed Abstract | Publisher Full Text

33. Foerstner KU, von Mering C, Hooper SD, et al.: Environments shape the nucleotide composition of genomes. EMBO Rep. 2005; 6(12): 1208-13. PubMed Abstract | Publisher Full Text | Free Full Text

34. Devriese LA, Vandamme P, Pot B, et al.: Differentiation between Streptococcus gallolyticus strains of human clinical and veterinary origins and Streptococcus bovis strains from the intestinal tracts of ruminants. J Clin Microbiol. 1998; 36(12): 3520-3. PubMed Abstract | Free Full Text

35. Narikawa S, Suzuki Y, Takahashi M, et al:: Streptococcus oralis previously identified as uncommon "Streptococcus sanguis" in Behçet's disease. Arch Oral Biol. 1995; 40(8): 685-90.

PubMed Abstract | Publisher Full Tex 


\section{Open Peer Review}

\section{Current Peer Review Status:}

\section{Version 1}

Reviewer Report 03 April 2013

https://doi.org/10.5256/f1000research.865.r872

(c) 2013 Gomez-Gil B. This is an open access peer review report distributed under the terms of the Creative Commons Attribution License, which permits unrestricted use, distribution, and reproduction in any medium, provided the original work is properly cited.

\section{Bruno Gomez-Gil}

CIAD, A.C., Mazatlán Unit for Aquaculture and Environmental Management, Mazatlán, Mexico

The article is well written with an appropriate title and abstract. The methods are adequate for the aims of the study, but I would suggest that including the Average Nucleotide Identity (ANI) analysis as suggested by Rosello-Mora et al. 2006, would certainly improve the manuscript. The online analysis can be found here http://www.imedea.uib.es/jspecies/index.html.The conclusions are adequate and the data sufficient to replicate all the analyses. The data are openly accessible at GenBank.

Competing Interests: No competing interests were disclosed.

I confirm that I have read this submission and believe that I have an appropriate level of expertise to confirm that it is of an acceptable scientific standard.

Reviewer Report 03 April 2013

https://doi.org/10.5256/f1000research.865.r818

(c) 2013 Sawabe T. This is an open access peer review report distributed under the terms of the Creative Commons Attribution License, which permits unrestricted use, distribution, and reproduction in any medium, provided the original work is properly cited.

\section{Tomoo Sawabe}

Laboratory of Microbiology, Graduate School of Fisheries Sciences, Hokkaido University, Hakodate, Japan

Title and abstract are good enough to attract readers in the scientific community.

Genome based multi-gene sequence comparison is one of the promising tools to analyse 
bacterial populations. To achieve the analysis for Streptococcus, the authors carefully designed massive data genome analysis. The results are strong enough and supported by the results of the analysis.

- The conclusion is clear that authors proposed a threshold value on the basis of genomebased MLSA in Streptococcus bacteria.

Competing Interests: No competing interests were disclosed.

I confirm that I have read this submission and believe that I have an appropriate level of expertise to confirm that it is of an acceptable scientific standard.

The benefits of publishing with F1000Research:

- Your article is published within days, with no editorial bias

- You can publish traditional articles, null/negative results, case reports, data notes and more

- The peer review process is transparent and collaborative

- Your article is indexed in PubMed after passing peer review

- Dedicated customer support at every stage

For pre-submission enquiries, contact research@f1000.com 